\title{
PARADIGMA DAKWAH ISLAM FETHULLAH GULEN DI ABAD KONTEMPORER
}

\author{
Akhmad Rizqon Khamami \\ Institut Agama Islam Negeri Tulungagung, Indonesia \\ E-mail: rizqonkham@yahoo.com
}

\begin{abstract}
This article seeks to examine Fethullah Gulen's da'wah activities by which he integrates his movement into the globalized world. Despite the fact that Turkish Coup in 2016 tarnished Gulen and his movement, and scholars come to question Gulen's intentions, Gulen's activities are to be explored so as for Islamic movements somewhere else to emulate his success in $d a^{w} w a h$. This article offers a perspective using the da'wah approach. Question under discussion in this article is as to which steps of da'wah lead Gulen movement to be a respected Islamic movement prior to the 2016. Gulen managed to widen the dawah from merely conventional da'wah such a that of preaching into educations, dialogues, and economic. It is indeed Gulen's emotional preaching that fascinates listeners and drives them voluntarily to engage in his activities of da'wah and to give hand to his missionary works which include building schools, TV stations, radios, hospitals, and banks. Gulen's da'wah in economic goes in line with his effort to broaden his influence on international level which in turn leads the movement integrated into the global economy. It is interfaith dialogue and pluralism that bring Gulen into integrating Islam with cosmopolitanism in the globalized world. Muslims no longer belong solely to ummah, but they are citizen of the globalized world.
\end{abstract}

Keywords: Fethullah Gulen; Gulen Movement; Gulen's da'wab; cosmopolitanism; hizmet.

\section{Pendahuluan}

Gulen Movement merupakan salah satu gerakan dakwah yang lahir di Turki di tengah pergolakan antara Islam dan sekularisme. ${ }^{1}$ Sebelum terjadi kudeta Turki 2016, para ilmuwan menganggap Gulen

\footnotetext{
${ }^{1}$ Hakan Yavuz dan Bayram Balci, "The Gulen Movement and the Coup", dalam Turkey's July $15^{\text {th }}$ Coup: What Happened and Why (Salt Lake City: The University of Utah Press, 2018), 7.
} 
Movement sebagai gerakan Islam moderat. Pada tahun 1998 Bulent Aras mengungkapkan pendapat Gulen bahwa peran agama tidak untuk mengatur kehidupan publik sebagaimana diyakini kelompok Islamis. $^{2}$ Bahkan gerakan ini disebut-sebut sebagai salah satu representasi gerakan Islam progresif. Sedangkan pada tataran ideologi Gulen Movement menawarkan jalan tengah antara sekularisme dan Islam. Berkat penyesuaian dengan atmosfer kontemporer dan menjadi gerakan internasional yang meleburkan diri dalam dunia global, Gulen dianggap membawa misi kosmopolitanisme. ${ }^{3}$

Tidak sedikit ilmuwan sejak awal menaruh curiga bahwa Gulen menyimpan misi terselubung di balik sikap moderat tersebut. Sabrina Tavernisa menuduh Gulen mengejar kekuasaan politik. ${ }^{4}$ Hakan Yavuz menyimpan sedikit kecurigaan, namun pakar politik Turki ini belum bisa mengidentifikasikan bentuk kekuasaan dan tujuan apa yang ingin digapai oleh gerakan Gulen kecuali setelah terjadi kudeta 2016 kecurigaan itu menjadi terang-benderang. ${ }^{5}$ Yavuz menyebut gerakan Gulen sebagai gerakan rahasia. ${ }^{6}$ James M. Dorsey mengomentari kudeta 2016 dengan menyebut Gulen sebagai konspirator dan "serigala yang berbulu domba". Tugrul Keskin berpendapat, sikap moderat Gulen dapat dilihat sebagai bentuk politisisasi gerakan Gulen dan politisisasi ini dapat dipahami sebagai faktor yang menjinakkan gerakan Gulen di tengah moda produksi kapitalis. ${ }^{8}$

Menurut hemat penulis, pendapat para ilmuwan tersebut muncul karena berangkat dari cara pandang mereka dengan menggunakan pisau analisis politik sehingga memunculkan kecurigaan. Menurut

2 Bulent Aras, “Turkish Islam's Moderate Face,” Middle East Quarterly, Vol. 5, No. 3 (1998).

3 Thijl Sunier, "Cosmopolitan Theology: Fethullah Gulen and the Making of a Golden Generation," Ethic and Racial Studies, Vol. 37, No. 12 (2014), 2193-2208.

4 Sabrina Tavernisa, "Tukish Schools Offer Pakistan a Gentler Vision of Islam," New York Time, 4 Mei 2008.

5 Hakan Yavuz and Rasim Koc, "The Turkish Coup Attempt: The Gulen Movement vs. The State," Middle East Policy, Vol. 23, No. 4 (2016), 147-148.

6 Hakan Yavuz, "The Three Stages of the Gulen Movement: From Pietistic Weeping Movement to Power-Obsessed Structure", dalam Turkey's July $15^{\text {th }}$ Coup: What Happened and Why (Salt Lake City: The University of Utah Press, 2018), 21.

7 James M. Dorsey, "Fethullah Gulen: Moderniser or Wolf in Sheep's Clothing?" Rajaratnam School of International Studies, No. 182 (18 Juli 2016).

8 Tugrul Keskin, "A Comparative Analysis of Islamist Movements in the Neoliberalization Process: Jama'at-e Islami in Pakistan and the Fethullah Gulen Movement in Turkey-Reactions to Capitalism, Modernity and Secularism" (Disertasi--Blacksburg, Virginia, 2009). 
penulis, agenda Gulen tidak lain adalah bentuk dakwah. Artikel ini menawarkan cara pandang dengan menggunakan pendekatan dakwah bahwa Gulen Movement tidak lain merupakan gerakan dakwah dan seluruh agendanya pun adalah agenda dakwah. Pertanyaan yang akan dikupas dalam artikel ini adalah apa saja aktivitas dakwah Gulen sehingga mengangkat gerakannya menjadi sebuah gerakan Islam yang cukup disegani sebelum kudeta Turki 2016. Penulis mendapati fakta menarik yang berbeda dari gerakan dakwah Islam lainnya-baik di Turki, maupun di negara Muslim lainnya seperti Indonesia-bahwa dakwah Gulen yang melingkupi ceramah, pendidikan, dialog dan ekonomi tidak lain merupakan upaya Gulen untuk mengikuti arus dunia yang sedang mengalami globalisasi. Seorang Muslim tidak sekadar warga negara sebuah negara Muslim, atau bagian dari entitas umat Islam, tetapi ia adalah warga negara dunia (global citizenship) dan bertanggung jawab atas perdamaian, kesejahteraan, keteraturan dunia, dan perputaran dunia.

\section{Peta Gerakan Dakwah di Turki}

Gulen menggenapi gerakan dakwah yang sudah ada di Turki. Beberapa gerakan dakwah di Turki antara lain adalah Milli gorus, Suleymanci, Kaplancilar, Haydar Bas dan Nurcu. Masing-masing gerakan ini berdakwah dengan metodenya sendiri-sendiri.

Gerakan dakwah pertama adalah Milli Gorus. Gerakan ini berdakwah melalui jalur politik. Milli Gorus ini digagas oleh Necmetting Erbakan. Pada tahun 1970 Erbakan dan pengikutnya mendirikan partai Islam pertama di Turki, yaitu Milli Nizam Partisi (MNP). Partai ini dibubarkan saat terjadi kudeta militer pada tahun 1971. Para pegiat partai ini lantas mendirikan Milli Selamet Partisi (MSP). Partai ini juga dibubarkan oleh pihak militer menyusul kudeta tahun 1980. Tak lama kemudian mereka mendirikan Refah Partisi. Setelah Refah Partisi dibubarkan oleh militer pada tahun 1997 dan Erbakan dilarang terlibat dalam dunia politik untuk masa lima tahun, para pengikut Erbakan mendirikan Fazilet Partisi (FP). Partai ini pun akhirnya dibubarkan oleh militer. Pengikut Erbakan terbelah. Sebagian membentuk Saadet Partisi. Sementara sekelompok anak muda mendirikan Adelet ve Kalkinma Partisi (AKP). AKP yang 
digawangi oleh Erdogan ini memenangi pemilu sejak tahun 2002 hingga sekarang. ${ }^{9}$

Gerakan dakwah kedua adalah Suleymanci. Gerakan ini berorientasi pada tasawuf dan memfokuskan pada pengajaran alQur'ān. Sebagai salah satu cara dakwahnya adalah menempatkan kader-kader terbaiknya di Kementerian Agama. Gerakan Suleymanci didirikan oleh Suleyman Hilmi Tunahan (1888-1959). Gerakan ini merupakan salah satu gerakan Islam tertua di Turki modern. Tunahan, seorang ulama dan tokoh tarekat Naqshabandīyah, mengembangkan gerakan dakwah dengan memfokuskan pada tiga hal, yaitu penguatan iman, pengajaran al-Qur'ān, dan pendirian asrama mahasiswa. ${ }^{10}$ Zurcher dan Van der Linden menyebutkan bahwa Suleymancis pernah bekerja sama dalam dakwah dengan pemerintah sekuler untuk memerangi gerakan komunis. ${ }^{11}$

Gerakan dakwah ketiga adalah Kaplancilar, atau jemaah Kaplan. Gerakan ini beraliran radikal revolusioner. Komunitas ini memiliki ribuan pengikut yang tersebar di negara-negara Eropa. Mereka pernah menguasai lima puluh masjid di Jerman sebelum dilarang oleh penguasa Jerman pada tahun 2001. Meskipun masjid mereka masih aktif, tetapi koordinasi di antara mereka mengalami kebuntuan karena Cemalettin Kaplan, Sang Pemimpin, telah diekstradisi ke Turki, dan dijatuhi hukuman penjara seumur hidup atas tuduhan berkonspirasi mengubah sekularisme Turki. ${ }^{12}$

Gerakan dakwah keempat adalah gerakan Haydar Bas. Gerakan ini berdakwah dengan menyebarkan pesan nasionalis-religius melalui berbagai media, misalnya Mesaj TV, Meltem TV, koran Yeni Mesaj, dan sejumlah majalah lainnya. Gerakan Haydar Bas didirikan oleh Professor Haydar Bas, dan merupakan cabang tarekat Qādirīyah. Mereka menjauhi interaksi dengan non-Muslim karena Kristen dan Yahudi dianggap ancaman terhadap Islam. Mereka juga memiliki

9 Lihat Akhmad Rizqon Khamami, "Erdoğan versus Gülen: Perebutan Pengaruh antara Islam Politik Post-Islamis dengan Islam Kultural Apolitik," al-Tabrir: Jurnal Pemikiran Islam, Vol. 16, No. 2 (2016).

${ }^{10}$ Hakan Yavuz, Islamic Political Identity in Turkey (London: Oxford University Press, 2003), 33.

${ }^{11}$ Erik J. Zurcher dan Heleen van der Linden, "Searching for the Fault-Line. A Survey of the Role of Turkish Islam in the Accession of Turkey to the European Union in the Light of the Clash of Civilization", dalam The European Union, Turkey and Islam (Amsterdam: Amsterdam University Press, 2004), 119.

12 Andreas Goldberg, "Islam in Germany," dalam Islam, Europe's Second Religion (Westport, CT: Praeger, 2002), 41. 
kendaraan politik tersendiri, yaitu Bagimsiz Turkiye Partisi (Partai Turki Merdeka). Gerakan ini juga memiliki jaringan bisnis dan sekolah. Menurut Kuru, gerakan ini memelihara pandangan negatif terhadap Barat dan antiglobalisasi, serta memperlihatkan cara berpikir intoleran. ${ }^{13}$

Gerakan kelima adalah gerakan Nurcu. Gerakan ini didirikan oleh Bediuzzaman Said Nursi (1876-1960). Ia adalah penulis kitab Risale-i Nur Kulliyati, sebuah kitab tafsir yang menggunakan pendekatan sains modern. Para pengikut Nursi membentuk komunitas pembaca Risale-i Nur. Para pembaca ini di kemudian hari mendirikan sebuah gerakan Islam yang dikenal sebagai gerakan Nurcu. Strategi dakwah Nursi berbeda dari gerakan Islam lain dalam melakukan transformasi masyarakat. Nursi berdakwah pada tataran individu. ${ }^{14}$ Selain itu, Nursi berupaya memadukan sains modern dengan Islam. ${ }^{15}$ Sejalan dengan perputaran waktu, gerakan Nurcu bercabang. Yavuz mengungkapkan bahwa faksi-faksi bermunculan dalam tubuh gerakan Nurcu mewakili dua kubu, yaitu kubu konservatif dan kubu progressif. ${ }^{16}$ Salah satu cabang yang mengadopsi pendekatan progresif adalah Gulen Movement.

Sebagai cabang dari gerakan Nurcu-Yavuz menyebut gerakan Gulen sebagai gerakan Neo-Nurcu-gerakan Gulen tidak masuk ke dalam kategori gerakan politik Islamis. Dalam pernyataannya Gulen tidak berkeinginan mendirikan negara Islam, bahkan ia tidak bermaksud mendirikan tarekat, karena gerakan Gulen bukan gerakan tarekat meskipun mereka bertasawuf. ${ }^{17}$ Gulen Movement merupakan hibrida antara tradisi Islam dan modernitas. Gerakan ini mengintegrasikan nilai Islam dan nilai Barat dengan menawarkan Islam progresif di tengah kompleksitas kehidupan modern. Gulen Movement memperlihatkan sikap terbuka dan dinamis dalam melakukan adaptasi terhadap dunia kontemporer. ${ }^{18}$ Proses

13 Ahmet T. Kuru, "Globalization and Diversification of Islamist Movements: Three Turkish Cases,” Political Science Quarterly, Vol. 120, No. 2 (2005), 266-268.

14 Hakan Yavuz, "The Gulen Movement, The Turkish Puritans", dalam Hakan Yavuz dan John L. Esposito, Turkish Islam and the Secular State. The Gulen Movement (New York: Syracuse University Press, 2003), 1-8.

15 Zurcher dan Linden, "Searching for the Fault-Line", 118.

${ }^{16}$ Yavuz, Islamic Political Identity, 179

${ }^{17}$ Lihat Akhmad Rizqon Khamami, "Tasawuf Tanpa Tarekat: Pengalaman Turki dan Indonesia”, Teosofi: Jurnal Tasawuf dan Pemikiran Islam, Vol. 6, No. 1 (2016).

18 Erol N. Gulay, "The Theological Thought of Fethullah Gulen: Reconciling Science and Islam” (Tesis--St Anthony's College, University of Oxford, 2007), 62. 
transformasi Gulen Movement dari sebuah gerakan lokal menjadi gerakan transnasional merupakan bukti sifat dinamisme dalam tubuh gerakan ini. Mayoritas pengikut Gulen adalah masyarakat Muslim Turki, namun bersamaan dengan berputarnya waktu, pengikut Gulen meliputi beragam etnis dan bangsa.

Menurut Kuru dan Zurcher, Gulen Movement adalah gerakan sipil keagamaan yang bersifat apolitis, non-profit dan non-violent. ${ }^{19}$ Meskipun Gulen Movement tidak pernah secara langsung berpartisipasi dalam partai politik, namun sebelum tahun 2011 Gulen dan para pengikutnya memiliki kedekatan dengan negara dan pemerintah Turki. ${ }^{20}$ Bahkan Gulen memperoleh kue kekuasaan dengan pemerintahan AKP pimpinan Erdogan sebelum keduanya pecah kongsi. ${ }^{21}$

Konsep dasar dakwah gerakan Gulen adalah hiæmet (pelayanan). Mereka meyakini bahwa melayani umat manusia adalah ibadah terbaik. Mereka mencari rida Tuhan dengan cara melayani manusia. Bahkan pengikut Gulen menyebut gerakan yang mereka ikuti sebagai gerakan bizmet. ${ }^{22}$ Melalui pelayanan, gerakan ini bermaksud menyelesaikan problem sosial, terutama kebodohan dan kemiskinan. Tidak seperti gerakan Islam lainnya, Gulen Movement mengembangkan sikap konstruktif terhadap globalisasi. Gulen Movement merupakan gerakan yang mengedepankan inovasi kreatif. Pandangan Gulen ini bersifat eklektik sebagaimana ditegaskan oleh Weller. ${ }^{23}$ Gerakan ini membedakan diri dari gerakan Islam lainnya dengan cara melakukan reformulasi isu-isu Islam di abad kontemporer. Gulen merupakan salah satu gerakan dakwah yang mengusung isu-isu kosmopolitanisme. ${ }^{24}$

${ }^{19}$ Kuru, "Globalization and Diversification", 261-265; Erik J. Zurcher, Turkey: A Modern History (London and New York: I.B. Tauris, 2007), 291.

${ }^{20}$ Berna Turam, Between Islam and the State: The Politics of Engagement (Stanford CA: Stanford University Press, 2007), 702. Lihat Newal Sevindi, Contemporary Islamic Conversation M. Fethullah Gulen on Turkey, Islam, and the West (Albany, NY: State University of New York, 2008), 703.

${ }^{21}$ Yavuz, "Three Stages of Gulen Movement", 40-41.

22 Lihat Martin E. Marty, Hizmet Means Service (Oakland, CA: University of California Press, 2015).

${ }^{23}$ Paul Weller, "Dialogue as a Source for Peaceful Co-Existence Between Muslim and Orthodox Christians in a Secular State," dalam Ihsan Yilmas (eds.) Peaceful Coexistence: Fethullah Gulen's Initiatives in the Contemporary World (Leeds: Leeds Metropolitan University Press, 2007), 280.

${ }^{24}$ Lihat Sunier, "Cosmopolitan Theology", 2193-2208. 
Gulen Movement mengalami pergeseran paradigma dalam dakwah. Pergeseran ini merupakan respons terhadap kondisi sosial. Gulen menggeser fokus dakwah dari sekadar dakwah normatif ke wilayah sosial. Tercapainya masyarakat yang disiplin dan teratur adalah cita-cita dan tujuan dakwah Gulen. ${ }^{25}$ Gulen menganggap pendidikan, media dan bisnis merupakan instrumen kunci dalam berdakwah. Dakwah Gulen melebur dalam dialog interkultural dan dialog antaragama. ${ }^{26}$ Ia memiliki ribuan lembaga pendidikan dan jutaan pengikut. Pertanyaan yang menggelitik, daya magnet apa yang menggerakkan ribuan orang untuk rela menjadi pengikut Gulen?

\section{Ceramah, Kaset dan Buku}

Gulen adalah seorang orator ulung yang mampu menggerakkan emosi pendengar. Ia menghadirkan ceramah agama yang bermuatan emosional ini. Ceramah emosional Gulen ini memikat berjuta-juta pengikut. Ia tidak segan-segan menangis tersedu-sedu ketika berceramah, menghayutkan pendengar untuk ikut menangis. Gulen tidak hanya menekankan secara verbal pentingnya berkomunikasi melalui sarana menangis, ia juga berusaha mencapai tujuan dalam ceramahnya dengan ikut menangis dengan menirukan suara perempuan jika ia sedang bercerita tentang kisah perempuan dalam sejarah Islam. ${ }^{27}$ Yavuz menyebut jemaah Gulen sebagai jemaah menangis (aglayan cemaat). ${ }^{28}$

Pada periode awal gerakan ini, dari tahun 1970 hingga 1983, Gulen berkeliling Turki sebagai seorang vair, khatib resmi negara. Gulen menyapa masyarakat Turki melalui khutbah dan ceramah. Pidatonya di kemudian hari dikasetkan dan disebarkan, terutama di daerah Anatolia. ${ }^{29}$ Kaset ceramah Gulen dijual di toko-tokoh buku. Semenjak memiliki stasiun TV, ceramah Gulen disiarkan melalui Samanyolu TV. ${ }^{30}$

\footnotetext{
${ }^{25}$ Yavuz, Islamic Political Identity in Turkey, 179-205.

${ }^{26}$ Lihat Akhmad Rizqon Khamami, "Dialog antar-iman dalam Perspektif Fethullah Gulen”, Religio: Jurnal Studi Agama-agama, Vol. 2, No. 1 (2012).

27 Esra G. Ozyurek, “'Feeling Tells Better than Language': Emotional Expression and Gender Hierarchy in the Sermons of Fethullah Gulen Hocaefendi”, New Perspectives on Turkey, Vol. 16 (1997), 45.

28 Yavuz, "Three Stages of Gulen Movement”, 26.

${ }^{29}$ Ibid., 26.

${ }^{30}$ Ozyurek, "'Feeling Tells Better than Language"'. 41.
} 
Ceramah Gulen meliputi beberapa topik: etika bisnis (2 ceramah pada tahun 1974); keesaan Tuhan (14 ceramah pada 1975); al-Qur'ān (32 ceramah pada 1976); Kenabian (39 ceramah dalam tahun 1975-76, 1989); Perempuan dalam al-Qur'ān (6 ceramah pada 1977); Hidup setelah mati/ hari kebangkitan (12 ceramah pada 1977-78); malaikat dan ruh (12 ceramah pada 1978); takdir (5 ceramah pada 1978); Puasa (5 ceramah pada 1979); Salat (9 ceramah pada 1978); Haji (5 ceramah pada 1978); zakat dan sedekah (9 ceramah pada 1979); Tuntunan Islam (14 ceramah pada 1979); ekonomi (28 ceramah pada 1979), etika (14 ceramah pada 1980); mendidik anak (10 ceramah pada 1977); Kualitas umat manusia (10 ceramah pada 1989); Suara dari mimbar (kumpulan khutbah pada 1975-1980); menuju cahaya (8 ceramah pada 1973-1979); dunia hati kita (9 ceramah 1979-1980); hak orang tua (1 ceramah pada 1991). Selain itu, Gulen memberi pengajian di masjidmasjid di sekitar Anatolia, terutama di bulan Ramadhan. ${ }^{31}$

Gulen berdakwah melalui dua media, yaitu media ceramah dan tulisan. Hasil ceramah, diskusi, khutbah dan pidato direkam oleh murid-muridnya, ditransliterasi, diedit oleh Gulen sendiri, dan lalu diterbitkan dalam bentuk buku. Buku tersebut mula-mula diterbitkan dalam bahasa Turki, dan beberapa di antaranya diterjemahkan ke dalam bahasa Inggris, antara lain: Toward the Lost Paradise (Izmir: Kaynak, 1998); Pearl of Wisdom (Fairfax, VA: The Fountain, 2000) and (New Jersey: The Light, 2005); Questions and Answers about Faith (Fairfax, VA: The Fountain, 2000); Criteria or Lights of the Way (London: Truestar, 2000); Essentials of the Islamic Faith (Fairfax, VA: The Fountain, 2000) and (New Jersey: The Light, 2006); Essays, Perspectives, Opinions (Rutherford, NJ: The Fountain, 2002); Emerald Hills of the Heart: Key Concepts in the Practice of Sufism (New Jersey: The Light, 2004); Toward a Global Civilization of Love and Tolerance (New Jersey: The Light, 2004); The Messenger of God. Mubammad: An Analysis of the Prophet's Life (New Jersey: The Light, 2005); The Statue of Our Souls: Revival in Islamic Thought and Activism (New Jersey: The Light, 2005). ${ }^{32}$

Buku Gulen dapat dikategorikan ke dalam dua jenis. Jenis pertama adalah kumpulan tulisan-tulisan Gulen dari berbagai media milik gerakan ini yang berisi paparan tentang nilai kemanusiaan dan

31 Gurkan Celik, "The Gulen Movement: Building Social Cohesion through Dialogue and Education” (Disertasi--Tilburg University, 2008), 14.

32 Ibid., 14-16. 
pelayanan (bizmet) kepada umat manusia. Contoh buku model ini adalah The Statue of Our Souls. Jenis buku kedua berisi transkrip ceramah dan wawancara. Selain itu, ada dua buah buku yang berada di luar dua kategori tersebut. Jenis pertama berisi kompilasi syair, berjudul Kirik Mizrap. Sedangkan jenis kedua adalah buku Gulen yang terbilang masterpiece dan ia tulis secara sistematis dan diterbitkan di majalah Sizinti dan majalah The Fountain adalah Emerald Hills of the Heart yang mengupas tentang tasawuf.

Memasuki tahun 1980-an Gulen memperkenalkan gaya ceramah model baru, yaitu model 'tanya-jawab'. Jemaah diajak untuk berpikir, merenung dan membaca situasi di sekitarnya. Mereka didorong untuk mengajukan pertanyaan tentang isu-isu sosial dan agama. Gulen menjawab semua pertanyaan. Ratusan kaset berisi ceramah 'tanyajawab' seperti ini diedarkan di pasaran. Tanya jawab tersebut diterbitkan menjadi buku. Buku ini kemudian diterjemahkan ke dalam bahasa Inggris dengan judul 'Questions and Answers about Islam'. Ceramah yang dibukukan ini diperuntukkan bagi pembaca yang lebih luas. Gulen bermaksud menyentuh semua lapisan masyarakat. Penulis melihat, dakwah dengan 'tanya-jawab' ini memiliki beberapa tujuan: mengajak jemaah untuk berpikir kritis; memperkuat iman; dimaksudkan sebagai panduan beragama dan membangun relasi dekat dengan jemaah.

Sejak tahun 1977 Gulen terlibat dalam sejumlah konferensi yang membahas topik-topik kontemporer seperti teori evolusi, keadilan sosial, dan nilai penting al-Qur'ān di zaman modern. Gulen juga terlibat dalam diskusi di café-café. Diskusi ini menjadi pondasi terbitnya majalah Sizinti pada tahun 1979. Majalah ini merupakan majalah pertama Gulen Movement untuk menyebarkan pesan dakwah. Tujuan penerbitan majalah ini adalah untuk merebut hati dan pikiran pembaca dengan menyediakan informasi tentang hubungan antara sains dan agama. ${ }^{33}$ Gulen secara konsisten menulis di majalah Sizinti sejak majalah ini terbit. Artikel tersebut umumnya berisi tulisan essai. Dalam tulisan-tulisan tersebut Gulen berdakwah tentang ajaran Islam, semangat ikhlas, khidmah dan nilai ibadah perjuangan. Tulisan Gulen di majalah ini merupakan sarana dakwah Gulen.

Di tahun 1990, Gulen berencana menyederhanakan buku Risale-i Nur ke dalam tulisan ringan dan popular agar buku ini mudah diakses oleh anak-anak muda yang kesulitan membaca Risale-i Nur yang ditulis

${ }^{33}$ Yavuz, "Three Stage of Gulen Movement", 27. 
bergaya Ottoman. Secara berkala tulisan sederhana Risale-i Nur tersebut diterbitkan di majalah Sizinti dan Yeni Umit. Akan tetapi gagasan ini mendapat penolakan dari kelompok Nurcu lain. Pengkritik berpendapat bahwa penyederhanaan buku tersebut akan menyebabkan hilangnya spirit yang dikandungnya. Meskipun Gulen tidak sependapat dengan pandangan mereka, akhirnya ia menghentikan rencana tersebut demi menghindari perselisihan. Gulen memutar haluan. Ia membuat proyek baru. Seluruh energi dicurahkan untuk mengupas tasawuf. Tulisan Gulen tentang tasawuf ini lantas diterbitkan ke dalam bahasa Inggris dengan judul 'The Key Concepts in the Practice of Sufism: The Emerald Hills of the Heart'. Dalam pandangannya, tasawuf adalah dimensi spiritual Islam. Tasawuf harus dihadirkan kembali di tengah konteks kehidupan kontemporer. ${ }^{34}$

Semenjak perpindahannya ke amerika, Gulen memulai pengajian sore. Di pengajian ini ia menjawab pertanyaan yang diajukan oleh jemaah pengajian. Jawabannya direkam dan diterbitkan dengan judul 'Kirik Testi'. Buku ini telah dicetak dalam enam jilid. Satu hal menarik, edisi baru buku-buku Gulen dibumbui dengan bibliografi dan referensi. Kebanyakan karya-karyanya merupakan sintesis dan artikulasi atas karya ulama terdahulu. Selain itu, dakwah Gulen ini bermetamorfosis dengan melahirkan bentuk dakwah baru melalui kolaborasi, partisipasi dan amal kegiatan dalam pendidikan, media dan ekonomi, serta melebur diri ke dalam arus dunia global dengan mengusung visi kosmopolitanisme dan menjadi gerakan internasional. ${ }^{35}$ Metamorfosis ini mendorong Gulen melakukan dialog antariman.

\section{Dakwah Dialog}

Gulen melihat dialog sebagai metode untuk mencapai perdamaian dan sebagai alat bagi masyarakat kosmopolitan untuk saling mengenal dan mempelajari satu sama lain. ${ }^{36}$ Dialog tidak mungkin dapat dicapai tanpa saling memahami dan saling bertoleransi. Baginya, dialog dapat diartikan sebagai sikap menerima orang lain dan bergaul secara baik. Gulen mempromosikan dialog peradaban melalui kerjasama dan

${ }^{34}$ Heon Choul Kim, "The Nature and Role of Sufism in Contemporary Islam: A Case Study of the Life, Thought and Teachings of Fethullah Gulen" (DisertasiTemple University, 2008), 188.

35 Yavuz, "The Three Stages of Gulen Movement", 30-31.

36 Fethullah Gulen, Toward a Global Civilization of Love and Tolerance (London: Truestar, 2004), 27-78. 
saling memahami. ${ }^{37}$ Ia menegaskan, dialog memerlukan atmosfer saling percaya dan saling hormat-menghormati. Melalui cara ini Gulen mencoba mengatasi ketegangan antara Islam dan Barat. Ia memimpikan terciptanya kohesi sosial dan harmoni di tengah masyarakat global. ${ }^{38}$

Gulen memanfaatkan dialog sebagai sarana dakwah. Ia melihat bahwa dialog merupakan instrumen kunci dalam membentuk masyarakat kosmopolitan. Secara implisit ia mendukung nilai-nilai demokrasi seperti kebebasan beragama dan kebebasan berbicara. Konsep Gulen tentang dialog meliputi tiga hal. Pertama, dialog adalah cara untuk menciptakan sikap saling menghormati. Kedua, dialog berisi penerimaan terhadap identitas orang lain. Ketiga, dialog adalah cara untuk saling berbagi nilai. Ketiga hal ini merupakan cara Gulen dalam membentuk masyarakat yang plural. ${ }^{39}$

Di wilayah dialog, aktivitas dakwah Gulen Movement berjalan secara efektif berkat organisasi Journalist and Writers Foundation (JWF). Organisasi ini berdiri pada tanggal 29 Juni 1994, dan dibentuk sebagai sarana untuk menciptakan dialog dengan kelompok lain. Lembaga ini memfasilitasi segala aktivitas dialog Gulen. Aktivitas dialog dengan nama Abant Paltform merupakan konferensi yang diselenggarakan setiap tahun. Penamaan pertemuan ini dengan nama "Abant" karena konferensi tersebut pertama kali berlangsung di kota Abant, Turki. Abant Platform diselenggarakan untuk memfasilitasi perdebatan-perdebatan politik. Abant Paltform diselenggarakan terakhir kali pada tanggal 6 Februri 2016. ${ }^{40}$

Dalam konferensi Abant, kelompok kiri, nasionalis, Islamis, sekuleris dan kelompok politik lain diundang untuk ikut berpartisipasi menyemarakkan konferensi tersebut. Peserta dalam konferensi ini meliputi para ilmuwan, jurnalis, penulis, intelektual dan politisi. Sebanyak 34 pertemuan Abant Platform telah diselenggarakan sejak tahun $1994 .{ }^{41}$ Konferensi ini berisi tema-tema aktual, tetapi temanya senantiasa berubah dari tahun ke tahun. Seringkali pemilihan topik mengandung isu kontroversial seperti isu Islam dan demokrasi,

\footnotetext{
${ }^{37}$ Lihat B. Jill Carroll, A Dialogue of Civilizations. Gulen's Islamic Ideals and Humanistic Discourse (New Jersey: The Light, 2007).

38 Gulen, Toward a Global Civilization, 33-34.

39 Bulent Aras dan Omer Caha, "Fethullah Gulen and His Liberal 'Turkish Islam' Movement." Middle East Review of International Affairs, Vol. 4, No. 4 (2000), 32-42.

${ }^{40}$ Yavuz, "The Three Stages of the Gulen Movement", 35.

${ }^{41}$ Ibid.
} 
sekulerisme, pluralisme, problem Kurdi dan demokrasi. Peserta acara bersikap kritis terhadap rezim Kemalis dan kelompok sekuler di Turki. Satu hal menarik untuk dipertanyakan adalah mengapa mereka memilih isu kontroversial dan bersikap kritis terhadap negara? Apa di balik pemilihan topik-topik tersebut? Tugrul Keskin menduga, semua itu memperlihatkan gerakan Gulen mengincar kekuasaan politik, tidak sekedar membincangkan persoalan hubungan Islam dengan isu-isu kontemporer semata. ${ }^{42}$

Gerakan Gulen memfasilitasi dialog antaragama, baik di dalam negeri maupun di luar negeri. Salah satu agenda besarnya adalah pertemuan antara Fethullah Gulen dengan Paus John Paul II pada tahun 1998 di Vatikan. Pertemuan ini dikritik oleh sejumlah kalangan. Satu kelompok menyebut Gulen terlalu besar kepala, seakan-akan menganggap dirinya sebagai kelompok yang dapat mewakili seluruh umat Islam. Mereka menyatakan, tidak selayaknya bagi sebuah kelompok Muslim berdialog dengan pemimpin tertinggi Katolik. Namun satu hal yang dapat kita tarik kesimpulan adalah bahwa melalui program dialog antariman semacam ini gerakan Gulen memosisikan diri sebagai gerakan yang sangat toleran terhadap agama lain.

Gulen mempercayai bahwa menghormati perbedaan dan keberagaman adalah sebuah kewajiban agama. Pemahaman Gulen terhadap agama dan masyarakat bersifat antroposentris. Pemahaman antroposentris seperti ini dapat dibaca bahwa metode membangun kohesi sosial adalah melalui dialog. Yilmaz meyakini bahwa Gulen menyerap ajaran Rumi tentang pentingnya membangun kohesi sosial. ${ }^{43}$ Gulen menekankan bahwa dialog interfaith adalah sebuah keharusan saat ini, dan langkah pertama dalam membangun dialog tersebut adalah dengan melupakan masa lalu, mengabaikan polemik yang pernah ada, dan mengutamakan titik-titik persamaan. Untuk memperkuat dakwah dialog ini Gulen juga menegaskan bahwa alQur'ān mendorong umat Islam untuk menghormati pengikut agama lain. Ia mendefinisikan dialog sebagai upaya dua orang atau lebih untuk saling bertemu untuk mendiskusikan isu-isu tertentu. ${ }^{44}$

\footnotetext{
${ }^{42}$ Keskin, "A Comparative Anylisis", 104.

43 Ihsan Yilmas, Peaceful Coexistence: Fethullah Gulen's Initiatives in the Contemporary World (Leeds: Leeds Metropolitan University Press, 2007), 40.

${ }^{44}$ Fethullah Gulen, Key Concepts in the Practice of Sufism: Emerald Hills of the Heart, Vol. 1-3 (Rutherford, NJ: The Fountain, t.th.), 42.
} 
Gulen mensyaratkan empat nilai agar dialog dapat terlaksana, yaitu cinta, rasa sayang, toleransi dan saling memaafkan. Empat nilai ini akan memudahkan dialog antaragama menemukan titik persamaan. Selain itu, dialog akan memberi manfaat jika para pengikut agama bersama-sama mempromosikan persamaan tersebut sebagai etika dasar bagi seluruh umat manusia. Gulen berpendapat bahwa agenda untuk saling bekerja sama antaragama dapat diperkuat dengan pengakuan atas perbedaan pada setiap agama dan menekankan pada resolusi konflik nir-kekerasan. Seseorang hendaknya mempelajari identitas budaya, keyakinan agama dan nilai-nilai spiritual orang lain agar bisa saling memahami.

Menurut Gulen, sikap positif merupakan prinsip dasar untuk dialog. Sikap positif menjauhkan diri dari sikap memusuhi cara pandang orang lain. Seseorang harus menjauhkan diri dari semua sikap dan perilaku yang menyebabkan konflik, permusuhan, pertengkaran dan ketegangan sosial. ${ }^{45}$ Seseorang mungkin saja memiliki kualitas yang tinggi dan kemampuan yang jenius, tetapi jika ia tidak menerapkan sikap positif dalam bergaul, maka kualitas unggulnya tidak akan mendatangkan kemanfaatan bagi masyarakat. Sikap positif ini merupakan prinsip dasar di balik Gulen Movement. ${ }^{46}$ Perilaku dan tindakan yang positif merupakan salah satu pondasi spiritual yang menjadi inti ajarannya.

Gulen dianggap sebagai salah satu ulama yang berusaha menerapkan "Turkish Islam", yaitu Islam dengan cita rasa Turki. Gulen berpendapat bahwa cara berislam warga Anatolia di Turki berbeda dari pemahaman Islam versi Arab (Salafi-Wahabi) dan Islam versi Iran (Shī`ah). Gulen meyakini bahwa masyarakat Turki menerapkan Islam versi Turki sepanjang sejarah bangsa ini. ${ }^{47}$ Masyarakat Muslim Anatolia berislam secara inklusif dan lebih toleran. "Turkish Islam" versi Gulen ini didasarkan pada moderasi, cinta, toleran, dialog, dan tasawuf. Dengan penekanan pada hal-hal tersebut Gulen sedang memperlihatkan bahwa bentuk Islam semacam ini tidak bertentangan dengan nilai kosmopolitanisme. Sebaliknya,

${ }^{45}$ Lihat Mehmet Enes Ergene, Tradition Witnessing the Modern Age: an Analysis of the Gulen Movement (Istanbul: The Light, 2008).

46 Thomas Michel, "Fethullah Gulen as Educator," dalam Hakan Yavuz dan John L. Esposito (eds.) Turkish Islam and the Secular State: The Gulen Movement (New York: Syracuse University Press, 2003), 69-84.

${ }^{47}$ Ali Unal dan Alphonse Williams, Advocate of Dialogue: Fethullab Gulen (Fairfax, VA: The Fountain, 2000), 54-58. 
sejumlah kelompok nasionalis mengkritik pemikiran tersebut. Para pengkritik berargumen bahwa menyebarkan pemikiran Islam semacam itu akan membuka lahirnya agama baru. Tetapi Keles berpendapat bahwa cara berislam masyarakat Anatolia bukanlah sebuah agama baru, tetapi hanyalah sebuah praktik beragama yang diselipi dengan nilai-nilai lokal. ${ }^{48}$ Gulen mendakwahkan kepada masyarakat konsep ini. $^{49}$

\section{Dakwah Pendidikan}

Gulen selalu menekankan pentingnya pendidikan, khususnya pendidikan bagi generasi muda. ${ }^{50}$ Ia menginginkan berdirinya sekolah unggulan dari kalangan Muslim yang bisa bersaing dengan lembaga pendidikan unggulan milik asing di Turki misalnya Robert College, St. Osep's dan German High School. Bahasa yang dipakai di sekolah asing tersebut adalah Jerman, Inggris, Perancis dan Italia. Sekolahsekolah tersebut membatasi diri hanya untuk kalangan tertentu dan menerapkan persyaratan masuk yang sangat ketat. Sehingga bagi mereka yang berasal dari kota kecil akan sulit mengakses sekolah papan atas tersebut, apalagi bagi mereka yang memiliki latar belakang keagamaan yang kental. Stratifikasi di sekolah tersebut menggambarkan kondisi strata sosial yang ada di tengah masyarakat Turki. Mereka yang bersekolah di lembaga pendidikan papan atas tersebut umumnya dari kalangan elit dan orang kaya. Padalah sekolah tersebut melahirkan generasi elit yang di kemudian hari akan memegang kendali perputaran negara dan rantai birokrasi di Turki.

Akhirnya, pada tahun 1982 Gulen berhasil mendirikan sekolah sendiri dengan karakteristik yang sama dengan sekolah unggulan di atas. Sekolah Gulen pertama ini dibuka di Izmir dengan nama 'Yamanlar'. Kemudian Gulen Movement membuka dua sekolah baru, yaitu Fatih College di Istanbul dan Samanyolu High School di Ankara. Bahasa pengantar yang digunakan adalah bahasa Inggris. Begitu juga sistem pendidikan dipilih sama seperti sekolah swasta asing tersebut. Bedanya, siswa yang terdaftar di sekolah Gulen tidak hanya berasal

\footnotetext{
48 Ozcan Keles, "Promoting Human Rights Values in the Muslim World: The Case of the Gulen Movement", dalam Ihsan Yilmas (eds.) Muslim World in Transition: Contributions of the Gulen Movement (Leeds: Leeds Metropolitan University Press, 2007), 692.

49 Elizabeth Ozdalga, "The Hidden Arab: A Critical Reading of the Notion of 'Turkish Islam"', Middle East Studies, Vol. 42, No. 4 (2006), 551-570.

${ }^{50}$ Gulen, Toward Global Civilization, 204-205.
} 
dari kalangan elit, pejabat ataupun orang-orang kaya saja, tetapi juga dari kalangan bawah.

Keruntuhan Uni Sovyet merupakan berkah bagi gerakan Gulen. Menyusul runtuhnya Uni Sovyet, bermunculan negara-negara merdeka di wilayah Eurasia yang membentang dari Bulgaria hingga ke Asia Tengah. Segera setelah Uni Sovyet bubar, gerakan ini berhasil mendirikan sekolah, jaringan bisnis dan pusat kebudayaan di Azerbaijan, Kazakhstan, Turkmenistan, Uzbekistan, Tajikistan dan Kyrgyzstan. Selanjutnya Gulen mendirikan kantor-kantor perwakilan di hampir semua negara. Di AS sendiri, sejumlah yayasan yang berafiliasi dengan gerakan Gulen bertebaran, misalnya Amity Turkish Cultural Center di Florida, Turkish Cultural Center di New York, Rumi Forum di Washington, D.C., Atlas Interfaith Foundation di California, American Turkish Friendship Association di Virginia, dan Lighthouse Foundation di New Jersey. Di Indonesia berdiri beberapa sekolah Gulen. ${ }^{51}$ Sejak itu gerakan Gulen menjadi gerakan internasional. ${ }^{52}$ Bahkan pasca-kudeta 2016, sekolah Gulen di negaranegara tersebut sulit dibubarkan oleh pemerintah Turki karena seluruh staf dan pengajar diisi orang-orang lokal. ${ }^{53}$

Salah satu struktur terpenting dakwah pendidikan Gulen adalah dershane (arti, rumah belajar). ${ }^{54}$ Dershane di dalam gerakan Gulen memiliki persamaan fungsi seperti halnya dershane dalam gerakan Nurcu lainnya, orang-orang akan bertemu sekali dalam seminggu, biasanya pada hari Jumat atau Sabtu malam. Sebagaimana dershane dalam kelompok Nurcu pada umumnya, Risale-i Nur dibaca dan didiskusikan oleh jemaah. Selain itu, dershane di gerakan Gulen berkembang menjadi isik evleri, yaitu tempat tinggal bagi sejumlah siswa. ${ }^{55}$

Gulen fokus dalam mendidik generasi muda di isik evleri dan mengajari mereka Islam. Di isike evleri ini bertempat sekitar lima hingga enam siswa. Mereka tinggal bersama seorang pembimbing yang dipanggil 'abi' (kakak), seorang pembina dengan kematangan usia dan

51 Heri Setyawan, "Nurturing Religious and Humanistic Values to Young Generations in Gulen and Jesuit Schools in Indonesia", Religio: Jurnal Studi Agamaagama, Vol. 6, No. 1 (2016), 30.

52 Yavuz dan Balci, "The Gulen Movement and the Coup", 11.

53 Ibid., 12.

${ }^{54}$ Sammy Aziz, "An Examination of the Dershane Phenomenon: Observations of Its Embodiment in the US and Turkey" (Tesis-Hartford Seminary, 2015).

55 Yavuz, "The Three Stages of the Gulen Movement", 20. 
ilmu agama. ${ }^{56}$ Ia bertugas membacakan Risale-i Nur dan menjelaskan kalimat per kalimat dalam pengajian. Selain buku Risale-i Nur, pemikiran Gulen juga diajarkan. Proses pengajaran semacam ini menciptakan solidaritas sosial, jejaring dan identitas kolektif di antara pengikut Gulen. Bagi kelompoknya, isik evleri memiliki dua manfaat. Pertama, memainkan fungsi sebagai tempat pendidikan agama dengan tujuan utama untuk menciptakan sosok yang taat beragama dan terbebas dari pengaruh negatif dunia luar. Kedua, memainkan fungsi bimbingan pendidikan. Di isik evleri, para mahasiswa senior akan membantu siswa yang lebih muda dalam menyerap pelajaran di sekolah, seperti fisika, biologi dan kimia.

Pendidikan sebagai fokus dakwah Gulen merupakan sumber inspirasi bagi seluruh aktivitas dakwah gerakan Gulen. Pendidikan berfungsi sebagai alat rekayasa sosial pada gerakan ini. Gulen menegaskan bahwa pendidikan dan pengajaran adalah kewajiban bagi seluruh manusia. Mendidik adalah tugas utama manusia. ${ }^{57}$ Selain itu Gulen menjadikan pendidikan sebagai metode efektif dalam mewujudkan perdamaian dan membangun kosmopolitanisme bagi siswa. Ia menegaskan bahwa pendidikan adalah hal pokok untuk menghilangkan problem kemanusiaan seperti teror, anarki dan konflik yang disebabkan oleh kebodohan, kemiskinan dan perpecahan. Ia memiliki keyakinan bahwa problem-problem tersebut hanya dapat diatasi dengan pengetahuan (melalui pendidikan) dan unifikasi (melalui dialog). ${ }^{58}$

Sekolah membentuk peace islands di mana beragam kultur dan peradaban bertemu dan menemukan konsensus bersama menuju perdamaian, kebebasan, persamaan hak dan kemajuan sosial. Sekolahsekolah Gulen berkontribusi mengatasi konflik. ${ }^{59}$ Gulen mendirikan sekolah di daerah-daerah konfik, seperti Albania, Kosovo, Macedonia, Filipina, Banda Aceh, Georgia, dan Iraq. Saritoprak dan Barton mengungkapkan bahwa melalui pendidikan pada generasi mudanya, sekolah-sekolah ini berperan menurunkan tensi konflik di daerah tersebut. $^{60}$

${ }^{56}$ Ibid., 29.

${ }^{57}$ Gulen, Toward a Global Civilization, 17.

${ }^{58}$ Unal dan Williams, Advocate of Dialogue, 306.

${ }^{59}$ Fethullah Gulen, The Essentials of the Islamic Faith (New Jersey: The Light, 2005).

${ }^{60}$ Zeki Saritoprak, "An Islamic Approach to Peace and Nonviolence: A Turkish Experience", The Muslim World, Vol. 95, No. 2 (2005), 423. 
Sekolah Gulen mendorong terwujudnya dunia yang ideal dimana para pelajar mampu berinteraksi dengan harmonis. Dunia yang ideal seperti itu dapat direalisasikan hanya oleh orang-orang yang dibekali dengan nilai-nilai moral dan kompetensi sehingga mereka mampu terlibat aktif di lingkungannya masing-masing dengan penuh toleransi dan penuh tanggung jawab. Bagi Gulen, para pengajar memainkan peran penting dalam merealisasikan dunia ideal semacam itu melalui pendidikan.

Altruisme menjadi prinsip dasar pendidikan Gulen. Guru-guru ikhlas mengajar. Mereka memiliki motivasi di luar motivasi finansial. Gulen menekankan pembangunan karakter sebagai bagian integral dari dakwah pendidikan ini. Para guru diharuskan memiliki perspektif global sehingga mereka mampu memelihara hati dan akal para pelajar dengan cara seimbang dalam membentuk aktor-aktor kosmopolit di tengah masyarakat global. Dalam dakwah pendidikan ini, titik fokus Gulen adalah pemberian contoh (temsi), bukan ceramah (teblig). Apa alasannya? Cara tebligh akan menjauhkan orang, sedangkan temsil mendekatkan. ${ }^{61}$ Para guru harus menjadi role-model bagai muridnya. ${ }^{62}$ Role model adalah prinsip dasar aktivitas dakwah pendidikan Gulen Movement. Menurut Gulen, para guru hendaknya menyerap nilai-nilai kejujuran dan mencintai sesama manusia. Selain menjadi role model (temsil), seorang pendidik harus sabar dalam proses pendidikan agar memperoleh hasil yang diinginkan. ${ }^{63}$

Para guru yang mengajar di sekolah-sekolah Gulen diwajibkan berperilaku sebagai role model untuk para murid. Guru adalah agen utama dalam aktivitas pendidikan Gulen Movement. Seorang pendidik membantu terbentuknya karakters dan personalitas siswa, dan ia mampu membantu siswa mengembangkan sifat mulia seperti disiplin, toleransi dan ikhlas. Sementara pengajar hanya berkutat pada transfer pengetahuan. Para pendidik harus mendidik setiap individu pada akal, jiwa dan karakter mereka. Para pengajar tidak hanya mentransfer pengetahuan dan memberi informasi, tetapi juga harus

${ }^{61}$ Bayram Balci, "Fethullah Gulen's Missionary Schools in Central Asia and their Role in Spreading Turkism and Islam", Religion, State and Society, Vol. 31, No. 2 (2003), 160-177.

${ }^{62}$ Yuksel A. Aslandogan dan Muhammed Cetin, "The Educational Philosophy of Gulen in Thought and Practice," dalam R.A. Hunt dan Y.A. Aslandogan (eds.) Muslim Citizens of the Globalized World. Contributions of the Gulen Movement (Somerset, NJ: The Light \& IID Press, 2006), 37.

${ }^{63}$ Unal dan Williams, Advocate of Dialogue, 312-13. 
memelihara seluruh personalitas para pelajar, baik dalam aspek intelektual maupun emosional. Pendidikan moral menjadi aspek dasar dalam mengintegrasikan identitas keislaman dengan realitas modern sehingga akan terbangun golden generation. ${ }^{64}$ Siapapun yang mendidik generasi muda hari ini, maka ia bertanggungjawab atas kebaikan dan keburukan 25 tahun yang akan datang. ${ }^{65}$

Thomas Michel, seorang tokoh Katolik, amat terkesan dengan sekolah-sekolah tersebut. ${ }^{66}$ Ia menggambarkan bagaimana suasana di atas dapat dilihat di sekolah Gulen selama tinggal di Zamboanga, di pulau Mindanao Filipina. Michel mengungkapkan bahwa PhilippineTurkish School of Tolerance di Zamboanga memperlihatkan semangat toleransi dengan komposisi pengajar Kristen dan Muslim yang berimbang, dengan siswa diisi dari kalangan Muslim dan anakanak Kristen seimbang pula. Sebagaimana amatan penulis saat berkunjung ke sekolah Gulen di Tangerang dan Semarang, siswa sekolah Gulen berasal dari beragam latar belakang etnis dan agama.

Sekolah-sekolah Gulen di Albania juga merupakan contoh baik tentang infusi ajaran kosmopolitanisme. Sekolah ini berdiri tepat di tengah masyarakat yang terbelah oleh agama. Populasi Albania terdiri dari Muslim Sunni, Muslim Bektashi, Katolik Roma dan Kristek Ortodok Yunani. Bekim Agai bercerita tentang bagaimana para guru di Albania menebarkan visi kemanusiaan kepada para pelajar karena Albania memiliki pengalaman pahit di bawah diktator yang kejam pada era komunis. Para guru membawa murid-murid ke orang-orang yang cacat dan hidup di bawah garis kemiskinan. ${ }^{67}$ Selain itu, sejumlah sekolah Gulen berdiri di Afrika. Misalnya di kota Johannesburg, Afrika Selatan. Sekolah ini diisi para siswa dari kalangan kalangan Kristen Afrika; di Durban kebanyakan adalah orang India Hindu; di Cape Town, sekolah Gulen diisi campuran antara Kristen dan Muslim.

Di sekolah ini anak-anak dari beragam etnis dan latar belakang dididik oleh para lulusan terbaik dari universitas papan atas. Dengan memberi pendidikan yang berkualitas, pada akhirnya sekolah Gulen memperoleh dukungan dan kepercayaan dari pemerintah dan masyarakat. Orang tua mengapresiasi para guru yang tidak merokok

${ }^{64}$ Yavuz, "Three Stages of Gulen Movement", 29.

${ }^{65}$ Gulen, Toward a Globalization, 205.

${ }^{66}$ Michel, "Fethullah Gulen as Educator", 69-84.

${ }^{67}$ Bekim Agai, "The Gulen Movement's Islamic Ethic of Education." Critique, Vol. 11, No. 1 (2002), 44-6. 
dan tidak minum minuman berakohol. Meskipun kebanyakan diinspirasi oleh pemikiran Gulen, para guru tidak mengajarkan agama. Mereka menekankan pada pengajaran etika yang dianggap sebagai faktor pemersatu antaragama, etnis dan politik. ${ }^{68}$

Visi besar Gulen adalah integrasi antara sains dan agama. ${ }^{69}$ Gulen melihat agama dan sains sebagai 'dua ekspresi dari satu kebenaran yang tunggal'. Untuk menyatukan antara iman dan rasio, Gulen menganggap agama dan sains sebagai dua aspek dari satu realitas yang saling melengkapi satu sama lain. ${ }^{70}$ Pendekatan Gulen ini mengintegrasikan antara pengetahuan sains dan nilai spiritual. Singkat kata, Gulen merekonsiliasi antara sains, rasio dan moralitas. ${ }^{71}$ Filsafat pendidikan Gulen didasarkan atas beberapa nilai. Gulen menghadirkan pendidikan sebagai solusi untuk problem umat, yaitu problem kebodohan. Ia meyakini bahwa kebodohan adalah problem yang paling serius. Kebodohan hanya dapat diselesaikan melalui pendidikan. $^{72}$

Menurut Michel, Gulen menawarkan keharmonian antara intelektualitas dengan spiritualitas yang berorientasi tasawuf di tengah konteks dunia modern. ${ }^{73}$ Gulay berpendapat bahwa, pemikiran Gulen memperkuat rasio dengan tradisi Islam, dan wahyu dihidupkan dengan prinsip rasionalitas dan pengetahuan saintifik. ${ }^{74}$ Ajaran Gulen dapat diringkas sebagai berikut: mengajarkan perdamaian, cinta, toleransi, mencari ridha Tuhan, tetap berpegang teguh pada moralitas, berperilaku baik dan mengabdi pada umat manusia (bizmet), rendah hati dan rela berkorban. ${ }^{75}$ Dengan tegas Gulen berpendapat bahwa semua ajaran tersebut adalah ajaran dasar Islam. ${ }^{76}$

\footnotetext{
${ }^{68}$ Ibid.

69 Lihat Akhmad Rizqon Khamami, "Integrasi Sains dan Agama: Perspektif Fethullah Gulen” (Disertasi--UIN Sunan Ampel Surabaya, 2016).

70 Berna Arslan, "Pious Science: The Gulen Community and the Making of a Conservative Modernity in Turkey" (Disertasi--University of California, 2009), 292.

${ }^{71}$ Agai, “The Gulen Movement's Islamic Ethic", 27-47.

72 Unal dan Williams, Advocate, 305-331.

73 Thomas Michel, "Sufism and Modernity in the Thought of Fethullah Gulen," The Muslim World, Vol. 95, No. 3 (2005), 341-358.

${ }^{74}$ Gulay, "The Theological Thought of Fethullah Gulen," 96.

75 Elizabeth Ozdalga, "Following in the Footsteps of Fethullah Gulen," dalam Hakan Yavuz dan John L. Esposito (eds.) Turkish Islam and the Secular State (New York: Syracuse University Press, 2003).

${ }^{76}$ Gulen, Toward a Global Civilization, 71.
} 
Gulen berpendapat bahwa orang tua adalah pendidik pertama, dan Gulen menekankan pada pendidikan keluarga yang baik. ${ }^{77}$ Gulen menegaskan bahwa pendidikan membutuhkan jaringan pendidikan yang berisi keluarga, sekolah, masyarakat, organisasi agama dan organisasi kultural, dan tempat kerja. Semua ini memungkinkan seorang individu mampu mengetahui sejak usia dini bahwa ia adalah anggota masyarakat yang harus hidup bersama orang lain secara harmonis dan damai. Visi pendidikan Gulen tidak hanya mencakup sekolah, tetapi juga keluarga, komunitas dan masyarakat dan bahkan dunia global yang kosmopolitan. ${ }^{78}$ Untuk mendukung kesuksesan pendidikan ini dibangun jejaring antara pendidik, orang tua dan penyokong dana. Berkat dukungan mereka, Gulen Movement mampu membangun ribuan sekolah yang tersebar di dunia. Sebelum terjadi kudeta 2016 Gulen Movement memiliki ribuan lembaga pendidikan yang berbentuk sekolah, lembaga kursus hingga universitas. Kegiatan ini disponsori oleh para pebisnis lokal, para relawan dan dukungan orang tua.

Gulen mengintegrasikan sikap toleransi ke dalam kuriklum sekolah. Gulen dan pengikutnya memperkenalkan sebuah model pendidikan yang menggabungkan ilmu pengetahuan, spiritualitas dan nilai etika. Gulen meyakini bahwa jalan menuju perdamaian dunia bergantung pada tersedianya pendidikan yang mengintegrasikan sains dan nilai etika, serta ketersediaan pendidikan multikultural. Hanya dengan cara tersebut, maka akan lahir pemahaman dan toleransi terhadap hak-hak orang lain. Gulen meyakini dengan cara inilah generasi baru akan muncul di tengah dunia global yang cosmopolitan, sebuah generasi yang disebutnya sebagai golden generation.

\section{Dakwah Ekonomi}

Keberhasilan Gulen Movement dalam bidang ekonomi dilihat sebagai salah satu kesuksesan dakwahnya. Elizabeth Ozdalga berasumsi bahwa kemajuan ekonomi Gulen Movement tidak lain karena buah dari pemikiran Gulen. Ozdalga berteori, Gulen berhasil meramu integrasi antara ekonomi dan agama. Pemikiran Gulen tidak sekedar berorientasi other-worldly. Sementara itu Joshua D. Hendrick menyebut Gulen Movement sebagai "marketized Islam”. Tugrul

${ }_{77}$ Unal dan Williams, Advocate of Dialogue, 310-311.

${ }^{78}$ Caroll, Dialogue of Civilizations, 74. 
Keskin berpendapat bahwa Gulen Movement adalah "domesticated Islam", yaitu Islam yang terjinakkan oleh pasar. Ekonomi pasar yang memiliki aturan dan cara kerjanya sendiri, di mata Tugrul Keskin, melahirkan proses interaksi unik antara Gulen Movement dan ekonomi pasar. Sifat dinamis ekonomi pasar memaksa Gulen Movement melakukan perubahan cara pandangnya terhadap ekonomi. Cara pandang ini disebut oleh Tugrul Keskin sebagai "Weberianization of Islam" atau "Jihad di Pasar". ${ }^{79}$

Penulis berasumsi bahwa Gulen dan gerakan Gulen berhasil "menaklukkan" pasar karena Gulen melihat pasar dan ekonomi adalah salah satu arena dakwah. Gulen menciptakan sebuah komunitas dengan elemen ekonomi. Gerakan Gulen mendirikan perusahaan yang mampu bersaing di pentas global. Gulen Movement berhasil mengembangkan gerakan yang tidak bertentangan dengan sistem neoliberal, baik di tingkat nasional maupun global. Gerakan Gulen berusaha memasukkan moralitas ke tengah pasar. Pertanyaan yang sering disampaikan kepada pengikut Gulen, "Hal baik apa yang akan dilakukan sesuai dengan tata aturan etika?" 80

Karakter kunci pembisnis dari kalangan pengikut Gulen adalah komitmen untuk meningkatkan kualitas pendidikan demi terciptanya sumber daya manusia yang unggul dan membawa Turki menuju era modern. Para pembisnis mendukung upaya ini melalui donasi yang berkisar 10 persen dari pendapatannya, bahkan sejumlah orang menyumbangkan sepertiga penghasilannya untuk mendukung lembaga pendidikan Gulen, rumah sakit, dan aktivitas dakwah lain. Tiga hal yang menjadi energy pendorong dalam mewujudkan aktivitas dakwah tersebut, yaitu perdagangan, pendidikan dan sedekah. Mereka menyumbang tidak saja sekolah Gulen di Turki, tetapi juga sekolah Gulen di luar negeri. Sebagai misal, pembisnis di Kutahya (Turki) menyumbangkan 15.000 dolar setiap bulannya untuk menyumbang pendidikan di Kyrgyzstan. ${ }^{81}$

Selain itu, keberhasilan gerakan ini dalam dakwah ekonomi dan bisnis berkat perubahan dalam kebijakan pasar seperti privatisasi dan deregulasi ekonomi Turki setelah kudeta militer tahun 1980. Militer Turki mengubah konstitusi yang lebih berpihak pada sistem ekonomi

${ }^{79}$ Keskin, “A Comparative Analysis of Islamic Movement”, 88.

${ }^{80}$ Phyllis E. Bernard, "The Hizmet Movement in Business, Trade, and Commerce", dalam Martin E. Marty (ed.) Hizmet Means Service (Oakland, CA: University of California Press, 2015), 145-146.

81 Ibid., 150. 
neoliberal dengan mengusung program privatisasi. Sejak itu tidak sedikit pakar ekonomi berkebangsaan Turki yang belajar dan bekerja di Amerika Serikat seperti IMF dan Bank Dunia ditarik pulang dan kemudian berperan aktif ikut mewarnai kebijakan negara. Gulen berhasil mengambil manfaat dari kebijakan privatisasi dan ekonomi neoliberal sejak kudeta 1980 .

Sebelum kudeta 2016, Gulen Movement memiliki koran Zaman yang beroplah hingga satu juta pembaca setiap harinya. Selain itu, gerakan ini juga memiliki majalah Sizinti, Ekoloji, Yeni Umit, Aksiyon, The Fountain, Burc FM, televisi Samanyolu dan Asya Finans. ${ }^{82}$ Setelah Gulen bermigrasi ke Amerika Serikat, gerakan ini mendirikan pusat Kebudayaan Turki di New York, Institute of Interfaith Dialogue di Houston, Atlas Foundation di Los Angeles, saluran televisi Ebru, Rumi Forum di Washington, D.C. dan koran harian berbahasa Inggris Today's Zaman. Gulen Movement adalah salah satu gerakan Islam di dunia yang memiliki jaringan luas dalam aktivitas dakwah globalnya.

Gulen ingin menyelaraskan antara ekonomi dan agama di tengah masyarakat Turki yang sekular. Ia mendorong umat Islam untuk melakukan integrasi ke dalam perputaran ekonomi dunia. Islam, tegas Gulen, diamalkan di wilayah privat, sedangkan di ranah publik umat Islam harus tunduk pada aturan publik dan bersedia terlibat dalam kegiatan ekonomi. Gulen tidak menentang ekonomi pasar maupun ekonomi neoliberal. Justru Islam dianggap paling cocok dengan model ekonomi ini. Gulen mengikuti pasar bebas. Ia menawarkan pemikiran yang berisi persesuaian antara Islam dan ekonomi pasar neoliberal. ${ }^{83}$

\section{Penutup}

Cara Gulen menyelaraskan Islam dan dunia kontemporer berbeda dari kelompok Islam lain seperti Milli Gorus, Haydar Bas dan lainnya. Ia menolak cara westernisasi yang pernah dilakukan oleh Mustafa Kemal Ataturk saat membangun negara Turki modern. Pemikiran Gulen ini sejalan dengan pendapat ilmuwan yang menegaskan bahwa proyek modernisasi Ataturk terbukti gagal. Modernisasi yang diterapkan di Turki modern merupakan modernisasi yang dipaksakan karena alat pendukung untuk memunculkannya secara alamiah-yaitu

\footnotetext{
82 Yavuz, "Three Stages of Gulen Movement", 30-31.

${ }^{83}$ Turam, Between Islam and the State, 51.
} 
kapitalisme dan industrialisasi-belum tercipta. Sebagai pendakwah agama Islam, Gulen menggerakkan simpatisan dan pengikutnya untuk mendukung aktivitas dakwah Gulen. Mereka mendirikan sekolah, stasiun TV, koran, majalah, bank dan asuransi.

Metode Gulen untuk meleburkan diri ke dalam sistem kapitalis global terbukti memperlihatkan hasil. Melalui dakwah pendidikan, dialog dan ekonomi, gerakan Gulen melebarkan sayap ke panggung internasional. Dakwah meluas hingga ke manca negara. Ribuan sekolah berdiri, dari Afrika, Amerika, hingga Asia, termasuk Indonesia. Selain mengajarkan sains, sekolah ini mengajarkan etika, sikap plural dan kosmopolit. Sekolah ini dimaksudkan sebagai tempat penggemblengan calon-calon warga negara dunia-bukan warga negara sebuah negara saja. Melalui aktivitas dakwah tersebut Gulen berhasil melakukan integrasi antara Islam dan kosmopolitanisme.

\section{Daftar Rujukan}

Agai, Bekim. "The Gulen Movement's Islamic Ethic of Education." Critique, Vol. 11, No. 1, 2002.

Aras, Bulent dan Caha, Omer. "Fethullah Gulen and His Liberal 'Turkish Islam' Movement." Middle East Review of International Affairs, Vol. 4, No. 4, 2000.

Aras, Bulent. "Turkish Islam's Moderate Face," Middle East Quarterly, Vol. 5, No. 3, 1998.

Arslan, Berna. "Pious Science: The Gulen Community and the Making of a Conservative Modernity in Turkey". Disertasi-University of California, 2009.

Aslandogan, Yuksel A. dan Cetin, Muhammed. "The Educational Philosophy of Gulen in Thought and Practice," dalam R.A. Hunt dan Y.A. Aslandogan (eds.) Muslim Citizens of the Globalized World. Contributions of the Gulen Movement. Somerset, NJ: The Light \& IID Press, 2006.

Aziz, Sammy. "An Examination of the Dershane Phenomenon: Observations of Its Embodiment in the US and Turkey". Tesis-Hartford Seminary, 2015.

Balci, Bayram. "Fethullah Gulen's Missionary Schools in Central Asia and their Role in Spreading Turkism and Islam", Religion, State and Society, Vol. 31, No. 2, 2003. 
Bernard, Phyllis E. "The Hizmet Movement in Business, Trade, and Commerce", dalam Martin E. Marty (ed.) Hizmet Means Service. Oakland, CA: University of California Press, 2015.

Carroll, B. Jill. A Dialogue of Civilizations. Gulen's Islamic Ideals and Humanistic Discourse. New Jersey: The Light, 2007.

Celik, Gurkan. "The Gulen Movement: Building Social Cohesion through Dialogue and Education". Disertasi--Tilburg University, 2008.

Dorsey, James M. "Fethullah Gulen: Moderniser or Wolf in Sheep's Clothing?" Rajaratnam School of International Studies, No. 182, 18 Juli 2016.

Ergene, Mehmet Enes. Tradition Witnessing the Modern Age: an Analysis of the Gulen Movement. Istanbul: The Light, 2008.

Goldberg, Andreas. "Islam in Germany," dalam Islam, Europe's Second Religion. Westport, CT: Praeger, 2002.

Gulay, Erol N. "The Theological Thought of Fethullah Gulen:

Reconciling Science and Islam". Tesis--St Anthony's College, University of Oxford, 2007.

Gulen, Fethullah. Key Concepts in the Practice of Sufism: Emerald Hills of the Heart, Vol. 1-3. Rutherford, NJ: The Fountain, t.th.

----. The Essentials of the Islamic Faith. New Jersey: The Light, 2005.

----. Toward a Global Civilization of Love and Tolerance. London: Truestar, 2004.

Keles, Ozcan. "Promoting Human Rights Values in the Muslim World: The Case of the Gulen Movement", dalam Ihsan Yilmas (eds.) Muslim World in Transition: Contributions of the Gulen Movement. Leeds: Leeds Metropolitan University Press, 2007.

Keskin, Tugrul. "A Comparative Analysis of Islamist Movements in the Neoliberalization Process: Jama'at-e Islami in Pakistan and the Fethullah Gulen Movement in Turkey-Reactions to Capitalism, Modernity and Secularism". Disertasi--Blacksburg, Virginia, 2009.

Khamami, Akhmad Rizqon. "Dialog antar-iman dalam Perspektif Fethullah Gulen”, Religio: Jurnal Studi Agama-agama, Vol. 2, No. 1, 2012.

-----. "Erdoğan versus Gülen: Perebutan Pengaruh antara Islam Politik Post-Islamis dengan Islam Kultural Apolitik," al-Tahrir: Jurnal Pemikiran Islam, Vol. 16, No. 2, 2016.

----. "Integrasi Sains dan Agama: Perspektif Fethullah Gulen". Disertasi--UIN Sunan Ampel Surabaya, 2016. 
-----. "Tasawuf Tanpa Tarekat: Pengalaman Turki dan Indonesia", Teosofi: Jurnal Tasawnf dan Pemikiran Islam, Vol. 6, No. 1, 2016.

Kim, Heon Choul. "The Nature and Role of Sufism in Contemporary Islam: A Case Study of the Life, Thought and Teachings of Fethullah Gulen”. Disertasi-Temple University, 2008.

Kuru, Ahmet T. "Globalization and Diversification of Islamist Movements: Three Turkish Cases," Political Science Quarterly, Vol. 120, No. 2, 2005.

Marty, Martin E. Hirmet Means Service. Oakland, CA: University of California Press, 2015.

Michel, Thomas. "Fethullah Gulen as Educator," dalam Hakan Yavuz dan John L. Esposito (eds.) Turkish Islam and the Secular State: The Gulen Movement. New York: Syracuse University Press, 2003.

----. "Sufism and Modernity in the Thought of Fethullah Gulen," The Muslim World, Vol. 95, No. 3, 2005.

Ozdalga, Elizabeth. "Following in the Footsteps of Fethullah Gulen," dalam Hakan Yavuz dan John L. Esposito (eds.) Turkish Islam and the Secular State. New York: Syracuse University Press, 2003.

----. "The Hidden Arab: A Critical Reading of the Notion of 'Turkish Islam"', Middle East Studies, Vol. 42, No. 4, 2006.

Ozyurek, Esra G. "'Feeling Tells Better than Language': Emotional Expression and Gender Hierarchy in the Sermons of Fethullah Gulen Hocaefendi", New Perspectives on Turkey, Vol. 16, 1997.

Saritoprak, Zeki. "An Islamic Approach to Peace and Nonviolence: A Turkish Experience", The Muslim World, Vol. 95, No. 2, 2005.

Setyawan, Heri. "Nurturing Religious and Humanistic Values to Young Generations in Gulen and Jesuit Schools in Indonesia", Religio: Jurnal Studi Agama-agama, Vol. 6, No. 1, 2016.

Sevindi, Newal. Contemporary Islamic Conversation M. Fethullah Gulen on Turkey, Islam, and the West. Albany, NY: State University of New York, 2008.

Sunier, Thijl. "Cosmopolitan Theology: Fethullah Gulen and the Making of a Golden Generation," Ethic and Racial Studies, Vol. 37, No. 12, 2014.

Tavernisa, Sabrina. "Tukish Schools Offer Pakistan a Gentler Vision of Islam," New York Time, 4 Mei 2008.

Turam, Berna. Between Islam and the State: The Politics of Engagement. Stanford CA: Stanford University Press, 2007. 
Unal, Ali dan Williams, Alphonse. Advocate of Dialogue: Fethullah Gulen. Fairfax, VA: The Fountain, 2000.

Weller, Paul. "Dialogue as a Source for Peaceful Co-Existence Between Muslim and Orthodox Christians in a Secular State," dalam Ihsan Yilmas (eds.) Peaceful Coexistence: Fetbullah Gulen's Initiatives in the Contemporary World. Leeds: Leeds Metropolitan University Press, 2007.

Yavuz, Hakan and Koc, Rasim. "The Turkish Coup Attempt: The Gulen Movement vs. The State," Middle East Policy, Vol. 23, No. 4, 2016.

Yavuz, Hakan dan Balci, Bayram. "The Gulen Movement and the Coup", dalam Turkey's July 15 th Coup: What Happened and Why (Salt Lake City: The University of Utah Press, 2018.

Yavuz, Hakan. "The Gulen Movement, The Turkish Puritans", dalam Hakan Yavuz dan John L. Esposito, Turkish Islam and the Secular State. The Gulen Movement. New York: Syracuse University Press, 2003.

----. "The Three Stages of the Gulen Movement: From Pietistic Weeping Movement to Power-Obsessed Structure", dalam Turkey's July 15 $5^{\text {th }}$ Coup: What Happened and Why. Salt Lake City: The University of Utah Press, 2018.

-----. Islamic Political Identity in Turkey. London: Oxford University Press, 2003.

Yilmas, Ihsan. Peaceful Coexistence: Fethullah Gulen's Initiatives in the Contemporary World. Leeds: Leeds Metropolitan University Press, 2007.

Zurcher, Erik J. dan Linden, Heleen van der. "Searching for the Fault-Line. A Survey of the Role of Turkish Islam in the Accession of Turkey to the European Union in the Light of the Clash of Civilization", dalam The European Union, Turkey and Islam. Amsterdam: Amsterdam University Press, 2004.

Zurcher, Erik J. Turkey: A Modern History. London and New York: I.B. Tauris, 2007. 